\title{
Assessment of peripheral blood concentration of angiopoietin 1, angiopoietin 2 and Tie-2 (a tyrosine kinase receptor) of patients with goitre treated surgically
}

\author{
Joanna Kalupa ${ }^{1}$, Krzysztof Kuzdak², Krzysztof Kołomecki \\ 1Department of General Surgery, MSWiA Hospital, Lodz, Poland \\ 2Department of Endocrine and General Surgery, Medical University, Lodz, Poland
}

Videosurgery and other miniinvasive techniques 2011; 6 (2): 64 -72 DOI: 10.5114/wiitm.2011.23212

\begin{abstract}
Introduction: Blood vessel formation by angiogenesis is essential for goitre development. Angiopoietin 1 (Ang-1), angiopoietin 2 (Ang-2) and Tie-2 receptor (rTie-2) are involved in part of angiogenesis. Ang-1 and rTie-2 expression increases in goitre.

Aim: To determine serum concentrations (SC) of angiogenic cytokines of patients with goitre treated surgically. Material and methods: Thirty-six patients with goitre aged 29-64 were examined. They were divided into groups: nontoxic nodular goitre (NTNG) and toxic goitre (TG). Each group was divided into subgroups: before and after surgery. The control group comprised 10 healthy subjects. Ang-1, Ang-2 and rTie-2 SC were measured in euthyroid subjects by ELISA. Measurements were performed before the procedure and three months after.

Results: Before surgery Ang-1 median (Me) SC in patients with TG was higher than in patients with NTNG (109 368 $\mathrm{pg} / \mathrm{ml} \mathrm{vs} .71185 \mathrm{pg} / \mathrm{ml}$ ) and in controls $(109368 \mathrm{pg} / \mathrm{ml} \mathrm{vs.} 57815 \mathrm{pg} / \mathrm{ml})$. Ang-1 Me in TG patients was higher prior to than after surgery $(109368 \mathrm{pg} / \mathrm{ml}$ vs. $65380 \mathrm{pg} / \mathrm{ml})$. Ang-2 Me in TG patients was higher after than prior to surgery $(4055 \mathrm{pg} / \mathrm{ml}$ vs. $3924 \mathrm{pg} / \mathrm{ml})$. Significant correlations were found between Ang-1 and Tie-2 Me ( $r=0.53)$ and Ang-2 and Tie-2 $(r=0.58)$ in patients with NTNG before surgery and between Me Ang-2 and Tie-2 in patients with NTNG after surgery $(r=0.89)$ and in controls $(r=0.77)$.

Conclusions: Before surgery in patients with TG SC of Ang-1 was higher than in patients with NTNG and in controls. After surgery in patients with TG SC of Ang-1 decreased, and SC of Ang-2 increased. Significant correlations were found between SC of Ang-2 and Tie-2 in patients with NTNG and in controls.
\end{abstract}

Key words: angiogenesis, angiopoietin 1, angiopoietin 2, Tie-2 receptor, goitre.

\section{Introduction}

In the areas with borderline iodine sufficiency numerous focal lesions are observed in the ultrasound scan in $0.6 \%$ of patients without goitre and in $24 \%$ of patients with goitre [1]. In Poland there may be around 1000000 patients with nodular goitre [2]. Although the reasons behind the formation of goitre are not entirely explained, immunological factors, genetic and environmental disorders are all taken into account, iodine deficiency being the most prevalent of them. Thyroid enlargement tends to occur during puberty, pregnancy and physiological lactation [3]. When concurrent thyroid nodules together with clinical and biochemical symptoms of hyperthyroidism are observed, toxic nodular goitre is diag- 
nosed [4]. Every solid tumour and goitre increase is possible only when new blood vessels are created, since they are supplied with oxygen and nutrients. New blood vessels sprout in the course of angiogenesis on the basis of the pre-existing ones. It is a crucial process for human reproduction, growth, development and wound healing. The following stages may be distinguished when a new capillary is formed: basement membrane degradation of maternal blood vessels, subsequent migration and proliferation of endothelial cells and newly formed tubular structures maturation. The last angiogenic stage maturation and stabilization of the vessel wall - relies mostly on angiopoietin activity [5]. Angiopoietin 1 (Ang-1) and angiopoietin 2 (Ang-2) are the best characterized. Angiopoietin 1 is the most crucial agonist for receptor tyrosine kinase Tie-2. It stimulates cell survival, maturation and vessel stabilization [6]. Angiopoietin 2 turned out to be a natural antagonist for the Tie-2 receptor [7]. It is expressed at the sites of vascular remodelling, where it blocks the stabilizing effects of angiopoietin 1 . It has been proven that Ang-2, similarly to Ang-1, when highly concentrated, is capable of stabilizing endothelial cells. Angiopoietin 2 activity is mainly upregulated by vascular endothelial growth factor (VEGF). Lack of VEGF causes Ang-2 to mediate vessel regression through apoptosis induction of endothelial cells. In the case of elevated VEGF concentration, angiopoietin-2 induces angiogenesis [8]. Receptor tyrosine kinase Tie-2 is observed in endothelial cells (endothelium). Tie-2 was also found in human follicular cells of the thyroid and its stronger expression was observed in the case of thyroid proliferation. Due to receptor Tie-2 presence in the endothelium, it participates in physiological angiogenesis and in neoplasm formation. Angiopoietins are also secreted by human follicular cells of the thyroid, and Ang-1 expression is increased in goitre induced by iodine deficiency [9]. Research shows that the Ang/Tie-2 complex appears to act during the later stages of vessel formation [10]. Not only does it support the survival and migration of endothelial cells, but it also regulates the modelling and integrity of the vessel wall [11]. The thyroid is believed to be one of the most vascularized organs among all the endocrine glands [12], and angiogenesis is essential for goitre formation. Thyroid diseases are surgically managed by performing subtotal or total thyroidectomy with a classic (open) approach [13] and by means of miniinvasive procedure [14]. Miniinvasive procedures include videoscopy without pneumoperitoneum formation (minimally invasive video assisted thyroidectomy - MIVAT) and with pneumoperitoneum formation. Minimally invasive techniques are thought to be equally safe as the classic technique [15]. Currently, the idea of full thyroid removal has gradually become a method of choice in surgical treatment of toxic and non-toxic goitre [16, 17]. A higher concentration of pro-angiogenic factors has been observed in cases of primary adrenal cortical carcinoma and in patients with adrenal metastases in comparison to healthy people [18]. Surgical treatment of adrenal diseases includes videoscopic techniques such as laparoscopic adrenalectomy [19, 20].

\section{Aim}

The aim of the study was to determine Ang-1, Ang-2 and receptor Tie-2 concentration in the serum of patients with toxic and non-toxic goitre directly before and 3 months after the surgical procedure and to investigate the relationship between determined cytokines. This could be used to learn about mechanisms of one of the angiogenic stages and possibly to create therapeutic methods supporting preparation for surgical treatment.

\section{Material and methods}

From the 36 evaluable patients, aged from 29 years to 64 years, 4 were male and 32 female. They were operated on in the Department of General Surgery, MSWiA Hospital in Lodz between 2007 and 2008 due to toxic and non-toxic goitre. A few weeks before the scheduled procedure all the patients initially qualified for the surgical treatment were interviewed and physically examined. The hormone levels of TSH and free thyroid hormones in blood - thyroxine (FT4) and triiodothyronine (FT3) - were determined. Ultrasonography (USG) examination of the thyroid was performed. In all the patients fine-needle aspiration biopsy (FNAB) under the control of USG was performed. Euthyroidism was defined when no clinical symptoms of thyroid dysfunction were observed with the correct relationship between hormones instrumental in regulating its function (TSH, FT3 and FT4 in the serum). Goitre identification and presence of nodules in physical examination and USG without accompanying thyroid dysfunction was defined as non-toxic nodular goitre. Nodular goitre 
identification together with clinical and biochemical symptoms of thyroid hyperfunction was defined as hyper-functioning nodular goitre [21]. Consecutive patients admitted to the department were qualified for the examination and surgical treatment. The patients with toxic nodular goitre were treated with the antithyroid drug thiamazole (Thiamazole, Merck KgA). The patients with non-toxic goitre did not receive any treatment. Finally, 36 patients qualified for the examination. In the patients no other ailments except for goitre were observed. All the patients who qualified for surgical treatment in the researched groups were in the euthyroid state. The patients were chosen randomly for the studied groups. The patients were divided into two groups on the basis of the clinical history and initial thyreometabolic state:

- group I (20 patients) contained patients with nontoxic nodular goitre (18 females and 2 males),

- group II (16 patients) contained patients with toxic nodular goitre (multinodular goitre) (14 females and 2 males).

Groups I and II were divided into subgroups A (patients before the procedure) and B (patients after the procedure). The mean age was 53 years. The con-

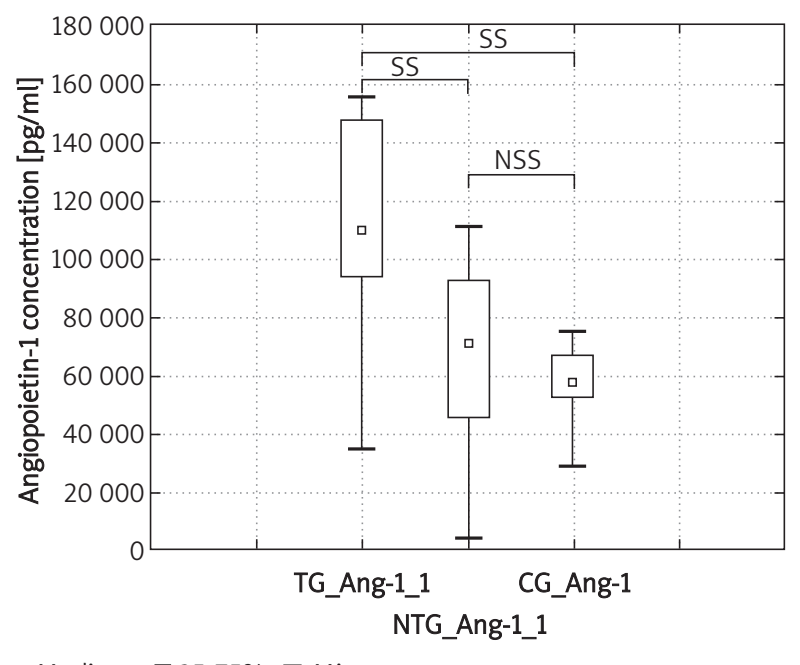

- Median $\square 25-75 \%$ I Min.-max.

TG_Ang-1_1 (group IIa) - Ang-1 concentration, toxic goitre, patients before the procedure

NTG_Ang-1_1 (group la) - Ang-1 concentration, non-toxic goitre, patients before the procedure

CG_Ang-1 - control group, SS - statistically significant, NSS - no statistically significant

Figure 1. Comparison of angiopoietin 1 concentration in the serum in the studied groups before the procedure and in the control group $(p<0.05)$ trol group (group III) contained 10 healthy volunteers aged 27 years to 68 years (average age 38 years). It included 4 women aged from 28 years to 35 years (32 years on average) and 6 men aged from 27 years to 68 years (27 years on average). In all the patients a total thyroidectomy was performed. Angiogenic factors were determined in the blood serum. The concentration of angiogenic factors Ang-1, Ang-2 and Tie2 receptor in the serum was determined in the euthyroid patients.

After the procedure all the patients received a hormone substance ensuring the euthyroid state. (levothyroxine - Euthyrox $\mathrm{N}$ by Merck). ELISA (enzyme-linked immunosorbent assay) was applied for the determination of cytokine profiles. Quantikine kits by R\&D Systems were used (R\&D Systems, Inc. 614 Mc Kinley Place N.E. Minneapolis, MN 55413; United States of America).

Determination was performed twice, on the day prior to the procedure and 3 months after the thyroid surgery in order to exclude the influence of wound healing on the determined values [22]. The permission no. RNN/458/07/KB was granted by the Commission of Bioethics at the University of Medicine in Lodz to carry out the research. The obtained results were statistically analysed by a demo version of STATISTICA 8. Shapiro-Wilk test, Kruskal-Wallis test, Mann-Whitney $U$ test, Wilcoxon test and Spearman rank correlation test were used for the analysis. Due to the abnormal distribution of tested parameters' values, descriptive statistics (median, minimal value, maximal value) were derived to characterize the studied groups. The 95\% confidence interval was accepted for the parameters analysed.

\section{Results}

Before the procedure, Ang-1 median concentration in the serum of the patients with toxic goitre was statistically significantly higher than Ang-1 median concentration in the serum of the patients with non-toxic goitre before the surgery $(109368$ pg/ml vs. $71185 \mathrm{pg} / \mathrm{ml}$ ) and higher than Ang-1 median concentration in the serum of patients from the control group (109 368 pg/ml vs. 57815 pg/ml) (Figure 1).

There were no statistically significant differences observed in Ang-2 median concentration in the serum among the patients with non-toxic goitre, with toxic goitre before the surgical treatment and the control group (Figure 2). There were also no sta- 


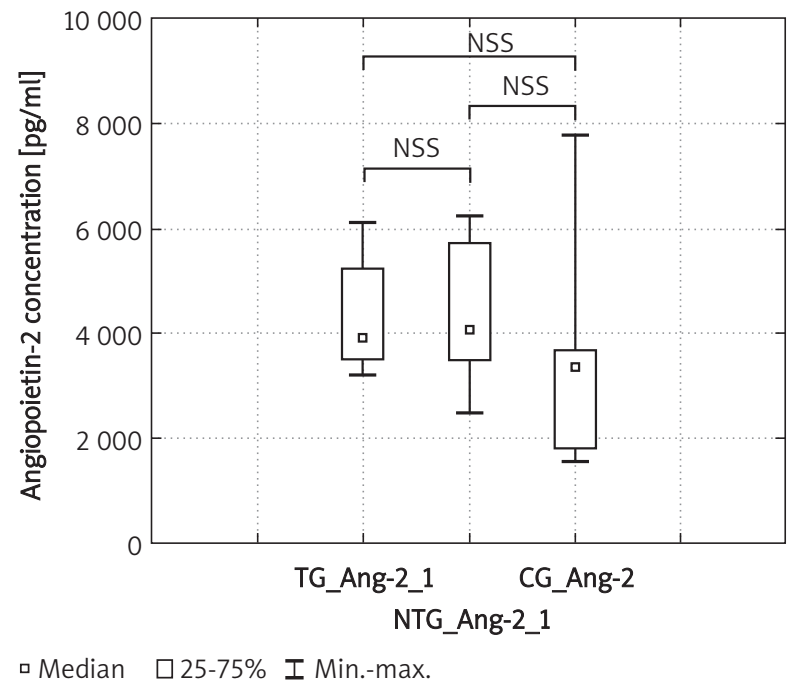

TG_Ang-2_1 (group IIa) - Ang-2 concentration, toxic goitre, patients before the procedure

NTG_Ang-2_1 (group la) - Ang-2 concentration, non-toxic goitre, patients before the procedure

CG_Ang-2 (group III) - Ang-2 concentration in the control group

Figure 2. Comparison of angiopoietin 2 concentration in the serum in the studied groups before the procedure and in the control group $(p<0.05)$

tistically significant differences observed in Tie-2 receptor median concentration in the serum between the patients with non-toxic goitre and toxic goitre before the procedure and the control group (Figure 3). In the series with toxic goitre statistically significantly higher median concentration of Ang-1 in the serum before the procedure was observed in comparison with the series with the toxic goitre after the procedure: 109368 pg/ml vs. 65380 pg/ml. In the patients with non-toxic goitre there were no statistically significant differences in angiopoietin 1 median concentration in the serum observed before and after the procedure: 71185 pg/ml vs. 74505.0 pg/ml (Figure 4). In the series with toxic goitre statistically significantly higher median concentration of Ang-2 was observed in the serum of the patients operated on than in the patients before the surgery: $4055 \mathrm{pg} / \mathrm{ml}$ vs. $3924 \mathrm{pg} / \mathrm{ml}$ (Figure 5).

In the group with non-toxic goitre there was no statistically significant difference in the median concentration of Ang- 2 in the serum before and after the procedure: 4036,5 pg/ml vs. $3849 \mathrm{pg} / \mathrm{ml}$. In the patients with toxic and non-toxic goitre there were

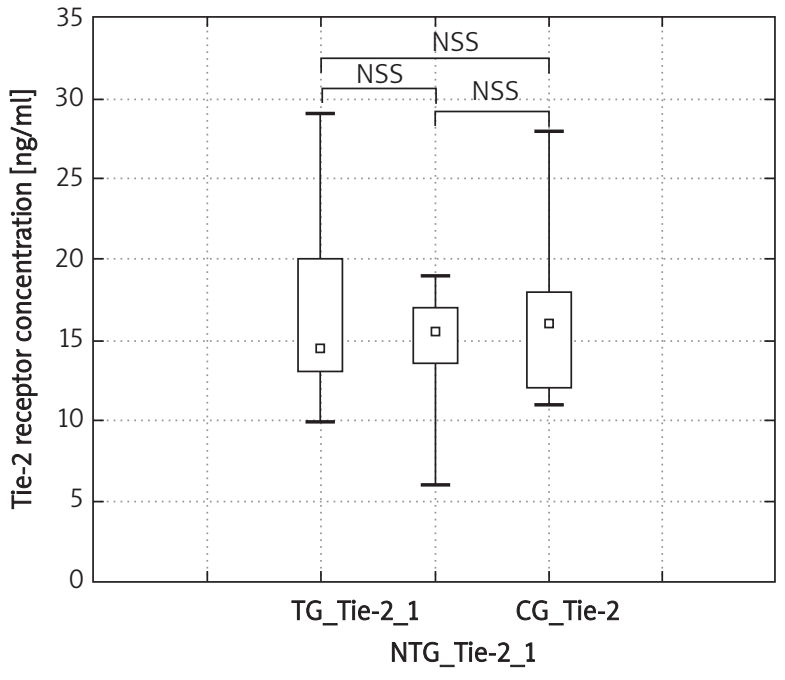

- Median $\square 25-75 \%$ I Min.-max.

TG_Tie-2_1 (group IIa) - Tie-2 concentration, toxic goitre, patients before the procedure

NTG Tie-2 1 (group la) - Tie-2 concentration, non-toxic goitre, patients before the procedure

CG_Tie-2 (group III) - Tie-2 concentration in the control group

Figure 3. Comparison of Tie-2 receptor concentration in the serum in the studied groups before the procedure and in the control group $(p<0.05)$

no statistically significant differences observed in the median concentration of Tie-2 receptor in both groups, the patients before the surgery and those operated on (Figure 6). In the serum of the patients with non-toxic goitre before the procedure there was a statistically significant, positive correlation observed between the values of Ang-1 and Tie- 2 median concentration $(r=0.53)$ and Ang-2 and Tie-2 $(r=0.58)$. A high, statistically significant, positive correlation ( $r=0.89$ ) between the values of Ang-2 and Tie-2 median concentration in the serum was observed in the patients with non-toxic goitre after the surgery $(r=0.89)$ and in the control group $(r=0.77)$. In the patients with toxic goitre before the procedure a statistically significant, average negative correlation between the values of Ang-1 and Ang-2 median concentration in the serum $(r=-0.53)$ and a statistically significant, average positive correlation $(r=0.5)$ between the values of Ang-1 and Tie-2 receptor were observed. There was no statistically significant correlation observed among median concentration of Ang-1, Ang-2 and Tie-2 receptor in the patients with toxic goitre. 


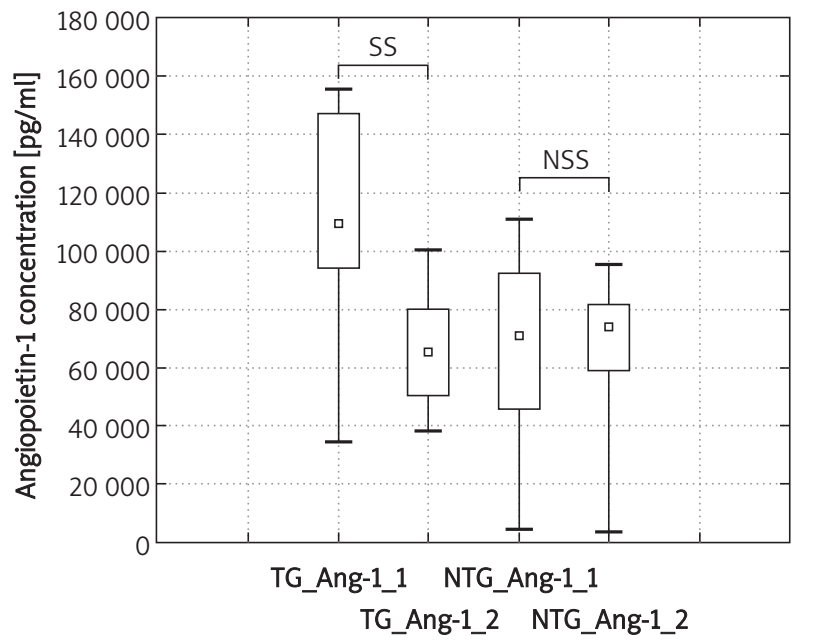

- Median $\quad \square 25-75 \%$ I Min.-max.

TG_Ang-1_1 (group Ila) - Ang-1 concentration, toxic goitre, patients before the procedure

TG_Ang-1_2 (group IIb) - Ang-1 concentration, toxic goitre, patients after the procedure

NTG_Ang-1_1 (group la) - Ang-1 concentration, non-toxic goitre, patients before the procedure

NTG_Ang-1_2 (group Ib) - Ang-1 concentration, non-toxic goitre, patients after the procedure

Figure 4. The influence of surgical treatment on angiopoietin 1 concentration in the serum of patients with toxic and non-toxic goitre $(p<0.05)$

\section{Discussion}

Angiogenesis occurs in several steps, including proliferation and endothelial cell differentiation and results from complex interactions between numerous proangiogenic and anti-angiogenic proteins [23, 24].

Angiopoietins and their receptors involved in the later stages of vessel formation and stabilization [24, 25] comprise a specific ligand-receptor complex. In a mouse model, angiopoietins and Tie-2 receptor deficit lead to severe microvascular defects.

Publications concerning the role of angiopoietins in endocrine system physiology are few. Studies on endocrine gland tumours predominate. Malignant tumours usually occur in the thyroid and adrenal glands; in the pituitary and parathyroid glands they are less frequent. Contrary to other neoplasms of the endocrine system, pituitary tumours are less intensely vascularized than the unchanged gland. Parathyroid induced angiogenesis occurs during autotransplantation [26]. In patients with adrenal cortical carcinoma higher concentration of angiogenic factors

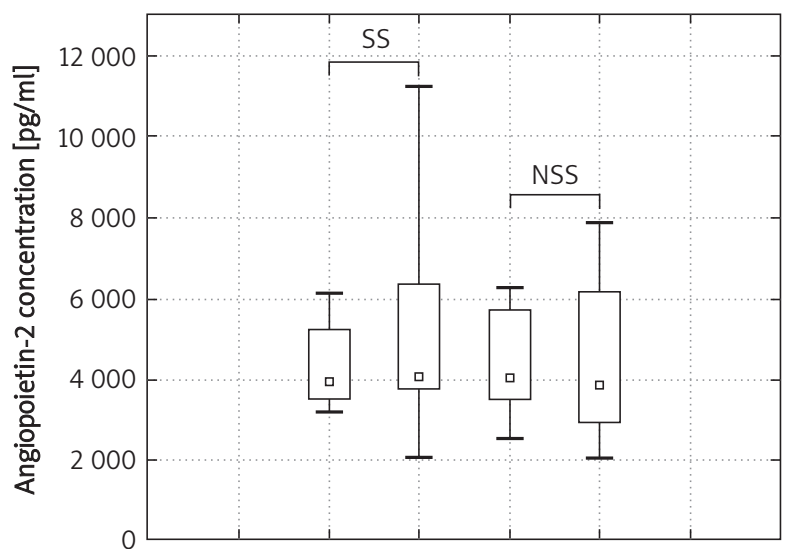

TG_Ang-2_1 NTG_Ang-2_1

TG_Ang-2_2 NTG_Ang-2_2

- Median $\square 25-75 \%$ I Min.-max.

TG_Ang-2_1 (group Ila) - Ang-2 concentration, toxic goitre, patients before the procedure

TG_Ang-2_2 (group I/b) - Ang-2 concentration, toxic goitre, patients after the procedure

NTG Ang-2 1 (group la) - Ang-2 concentration, non-toxic goitre, patients before the procedure

NTG_Ang-2_2 (group la) - Ang-2 concentration, non-toxic goitre, patients after the procedure

Figure 5. The influence of surgical treatment on angiopoietin 2 concentration in the serum of patients with toxic and non-toxic goitre $(p<0.05)$

was observed in comparison to healthy persons [18]. Apart from morphological changes in the thyroid gland (shape and size of thyrocytes), the concentration of thyroid stimulating hormone (TSH) and free thyroid hormones in blood constitute a biochemical proof of euthyroidism. Thyroid stimulating hormone is secreted by the pituitary gland and it is the best known stimulus for increasing thyroid growth and goitre formation [24, 25]. Thyroid stimulating hormone induces the increase in VEGF and secondarily the change of angiopoietin concentrations [24, 27]. The literature with regard to angiopoietins' functions in the physiology and pathology includes studies concerning their expression in the examined organs and concentration in the body fluids (blood, saliva, intraperitoneal fluid). The expression of angiogenic factors (Ang-1, Ang-2, Tie-2 receptor, VEGF) in the thyroid gland and their concentration in the blood serum has been described in a work about immunological thyroid disease (Graves' disease) which has been published only recently [28]. A positive correlation between mRNA for Ang-2 and Tie-2 in the thyroid 
gland and serum has been observed. Although it is a single report, the possibility to assess expression of cytokines in the organ on the basis of their concentration in the body fluids (blood) is promising enough to base the research discussion on the assumption that their blood concentration is related to the expression in the organ examined. In the publication with an equal concentration of TSH in the patients' serum, statistically significantly higher concentration of Ang-1 in the patients with toxic goitre than in the patients with non-toxic goitre was observed. Such a situation can be explained both by the fact that in the case of toxic goitre the process of angiogenesis is intensified and accompanied by the increase of proangiogenic angiopoietin 1 and also by the proangiogenic influence of the antithyroid drug [27]. In 2001 Ramdsen and his team presented their research concerning the occurrence and function of angiopoietins in the thyroid gland [9]. They observed increased expression of Ang-1 in the human thyroid follicular cell culture obtained from a goitre after surgical treatment. The research showed higher concentration of Ang-1 in patients with toxic goitre than in patients with non-toxic goitre and healthy persons.

The stabilizing effect of angiopoietin 1 on the vessels was confirmed by the examination of COMP (cartilage oligomeric matrix protein) derived from the intestinal villi. Ang-1 prevents arterial hypertension and organ damage caused by high arterial pressure by the vascular anomalies alternation [29]. The study revealed considerably lower Ang-1 concentration, and higher concentration of Ang-2 in serum of patients with toxic goitre after the surgery, which appears to contradict the stabilizing function of Ang-2. This may be the result of goitre and thyroid gland absence as a source of angiopoietins secreted into blood.

Angiopoietin 1 remaining after the surgery may have different properties than Ang-1 in patients with non-toxic goitre and despite a lower level still has a positive influence on the vessels. Lower concentration of Ang-1 was observed in patients with thyroid tumours than in healthy persons [30]. This observation results from Ang-1 determination in the tumour tissue in the area where necrosis is predominant and new vessel formation is poorly expressed or possibly vessel creation with Ang-2 is predominant and it requires VEGF cooperation. After analysing the publications connected with the influence of different methods of surgical treatment on angiogenic factors,

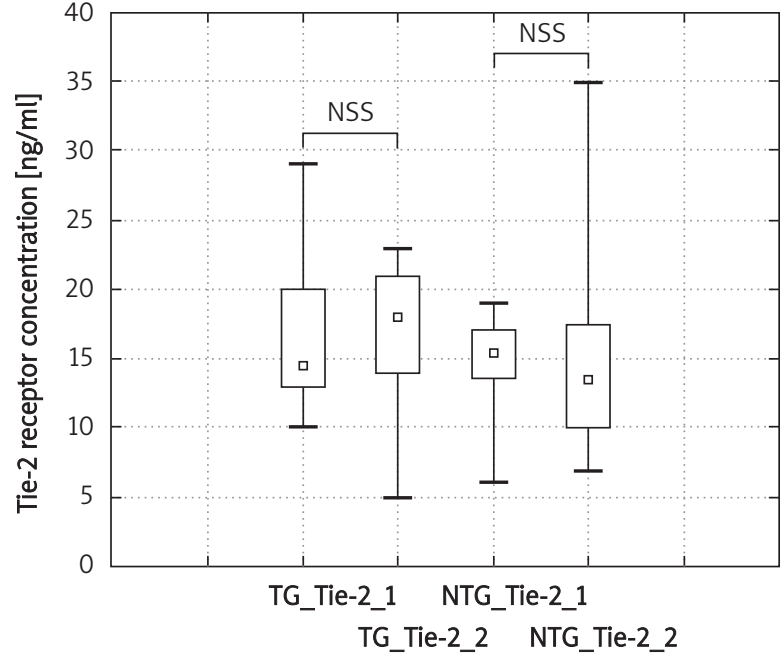

- Median $\quad$-25-75\% I Min.- max.

TG_Tie-2_1 (group IIa) - Tie-2 concentration, toxic goitre, patients before the procedure

TG_Tie-2_2 (group IIb) - Tie-2 concentration, toxic goitre, patients after the procedure

NTG Tie-2_1 (group la) - Tie-2 concentration, non-toxic goitre, patients before the procedure

NTG Tie-2 2 (group Ib) - Tie-2 concentration, non-toxic goitre, patients after the procedure

Figure 6. The influence of surgical treatment on Tie-2 concentration in the serum of patients with toxic and non-toxic goitre $(p<0.05)$

it was noted that the treatment duration is diverse (it varies from a few weeks to a few months) [31-33]. This fact may influence the obtained results. There is a possibility that after prolonging the observation period up to e.g. a year, researchers would attain considerably different results, and the concentration of angiogenic factors in the examined fluids would be normalized. Tie-2 concentration was higher in patients with active Graves ophthalmopathy in comparison to patients with inactive Graves ophthalmopathy and patients without ophthalmopathy [28]. No statistically significant differences in Tie-2 concentration in the serum between the studied groups (toxic and non-toxic goitre) before and after the procedure were described in the work. In the examined patients with goitre there was no immunological process (no TSH antibodies in the serum), which may explain why there were no changes in Tie-2 receptor in our study group. Ramsden, in one of his publications [9] regarding angiogenesis, reported the presence of Tie-2 receptor in the thyroid follicular cells and its elevated expression in the human goitre (thy- 
roids from surgical treatment were examined). The lack of differences observed in our patients may result from the fact that the study group in Ramsden's work might include patients whose angiogenesis was mildly intensified due to the length of the disease and the predominance of reverse processes.

One of the first publications concerning the influence of surgical treatment on concentration of angiogenic factors was a work from 2001 by Polish authors. They observed VEGF increase after the surgery in the serum of patients treated due to Graves' disease [33]. Angiogenic cytokines participate in postsurgical wound healing [22], so their concentration in the operated tissue and blood increases during the perioperative period. To learn more about surgical treatment influence on the concentration of these cytokines in blood, a control examination was performed at least 3 months after the procedure. In patients operated on due to breast cancer and then undergoing chemo- and/or radiotherapy, Caine et al. observed the normalization of VEGF and Ang-1 3 months after the combined treatment, and Tie-2 1 year after the procedure. In the study a fall in Ang-1 concentration in patients with toxic goitre 3 months after the thyroidectomy was noted. It can be explained by the absence of goitre as a source of angiopoietins secreted to the blood, and also perhaps by the lack of thyreostatic treatment, as a secondary factor causing stimulation of angiogenesis and increase of angiopoietins. It could confirm Wollman's theory of the proangiogenic effect of antithyroid drugs [27].

The influence of surgical treatment on VEGF in the blood serum and plasma is not entirely explained. Kołomecki et al. [33] when examining patients after strumectomy performed due to Graves' disease observed an increase of VEGF on the $7^{\text {th }}$ day after the procedure. They explained such results by the influence of repair processes taking place during wound healing in the thyroid gland. Apart from wound healing there seemed to be another, additional reason for this phenomenon. In a Russian-Swedish study where wound healing after endometriosis surgical treatment was described, VEGF decrease occurred [32].

An American publication from 2007 shows that VEGF levels in plasma of patients after miniinvasive surgery of colorectal carcinoma increases. Blood samples for examination were taken on the $1^{\text {st }}, 2^{\text {nd }}, 3^{\text {rd }}$, and $4^{\text {th }}$ day after the procedure. The assessment of surgical treatment influence on cytokine concentrations in blood is one of the ways of learning about angiogenic mechanisms. Due to limited research with regard to this matter it is difficult to decide whether the alteration of angiogenic cytokine concentrations results from surgical treatment or is simply accidental. In the studied groups a few statistically significant correlations were observed. In patients with toxic and non-toxic goitre there is a statistically significant, positive correlation between Ang- 1 and Tie-2 receptor concentration in the serum. Caine et al. observed a correlation between Ang- 1 and Tie- 2 concentration in the serum of patients with breast carcinoma and benign mammary dysplasia before the surgical treatment [34]. A positive, statistically significant correlation between Ang-2 and Tie-2 receptor in blood of patients with non-toxic goitre was observed. The same correlation between Ang-2 and Tie-2 occurred only in patients with breast carcinoma before the surgical treatment. Caine did not include in the analysis of results of his research the kind and value of the correlation coefficient after surgical treatment. The author suggests that the occurrence of Ang- 1 and Tie- 2 correlation in both studied groups, i.e. patients with benign breast dysplasia and breast carcinoma, suggests physiological, not pathological character of the relationship. In the research the type of correlation did not change in patients with nontoxic goitre after the surgical treatment. In patients with toxic goitre before the procedure a negative, statistically significant correlation between Ang-1 and Ang-2 concentration in blood serum was observed. Caine, in his other publication regarding breast and prostate cancer in patients not operated on, also observed a significant correlation between Ang- 1 and Ang-2 in blood [35]. In his study the correlation was positive, which may result from the nature of the investigated diseases, neoplasms, while in this work benign thyroid diseases were analysed.

The next interesting relationship is a statistically significant correlation between Ang-2 and Tie- 2 concentration in blood of patients with non-toxic goitre and the control group. It is consistent with Caine's results in patients with prostate and breast cancer and his researched group [35]. The same correlation between Ang-2 and Tie-2 in blood serum was observed by Polish authors in patients with anaplastic thyroid carcinoma (ATC) [30].

It should be mentioned here that mathematical confirmation of the relation does not always prove a cause and effect relationship between variables. 
Correlation of two events may also result from the direct influence of a third event. Mexican authors in their publication from 2009 [26] described a positive correlation between free thyroxine in the serum and Tie-2 receptor and angiopoietin 2 concentration in the blood of patients with Graves' ophthalmopathy. They also suggested a biological relationship between thyroxine and angiogenic cytokine concentration in blood. However, the confirmation of such a relationship requires further studies focused on the problem itself. The creation of standardized methods of tissue expression and angiogenic cytokines in the examination of body fluids could be used to monitor both pharmacological and surgical treatment.

In the research the crucial role of angiogenesis in hyper-functioning goitre formation, as proven on the basis of pro-angiogenic Ang-1 concentration increase before the procedure and the negative correlation between Ang-1 and Ang-2, having antagonistic effects, was demonstrated. The increased concentration of pro-angiogenic factors may have numerous implications in those patients. The angiogenic process elevated for many months may stimulate the formation of dormant carcinoma. Angiogenesis plays an important role in patients with cardiovascular diseases, which is why the imbalanced pro- and anti-angiogenic factors in patients with hyper-functioning goitre, confirmed in this research, may possibly influence the course of these diseases. The fact that elevated angiogenesis in the thyroid gland may cause increased intraoperative bleeding is also not without significance. The ability to influence the process of angiogenesis could increase the safety of surgery performed on patients with huge, often retrosternal goitre. The proven decrease of Ang-1 concentration suggests postoperational normalization of concentration of angiogenic factors, which can considerably influence many functions of the patient. Pharmacological treatment, which does not remove the goitre, the source of angiogenic factors, cannot lead to a decrease of angiogenic factors, but to the euthyroid state.

\section{Conclusions}

1. Better blood supply in patients with toxic goitre than in patients with non-toxic goitre may be connected with the considerable angiogenesis stimulation.

2. After the surgery, the activity of angiogenic processes is increased, which may be connected with removal of the thyroid gland, the source of proangiogenic cytokines.

3. Numerous correlations between angiogenic factors exist.

\section{References}

1. Rago T, Chiovato L, Aghini-Lombardi F, et al. Non-palpable thyroid nodules in a borderline iodine-sufficient area: detection by ultrasonography and follow-up. J Endocrinol Invest 2001; 24: 770-6.

2. Program eliminacji niedoboru jodu w Polsce na lata 2006-2008, Warszawa, marzec 2006. Available at: www.mzios.gov.pl.

3. Samuels MH. Evaluation and treatment of sporadic nontoxic goiter - some answers and more questions. J Clin Endocrinol Metab 2001; 86: 994-7.

4. Tonacchera M, Chiovato L, Pinchera A, et al. Hyperfunctioning thyroid nodules in toxic multinodular goiter share activating thyrotropin receptor mutations with solitary toxic adenoma. J Clin Endocrinol Metabol 1998; 83: 492-8.

5. Kopczyńska E, Makarewicz R, Tyrakowski T. Rola angiopoetyn 1 i 2 w regulacji angiogenezy nowotworowej. Współcz Onkol 2007; 11: 350-4.

6. O'Reilly MS. Angiostatin: an endogenous inhibitor of angiogenesis and of tumor growth. In: Regulation of angiogenesis. Goldberg ID, Rosen EM (eds.). Switzerland: Basel 1997.

7. Maisonpierre PC, Suri C, Jones PF, et al. Angiopoietin-2, a natural antagonist for Tie2 that disrupts in vivo angiogenesis. Science 1997; 277: 55-60.

8. Harfouche R, Hussain SNA. Signaling and regulation of endothelial cell survival by angiopoietin-2. Am J Physiol Heart Circ Physiol 2006; 291: H1635-45.

9. Ramsden JD, Cocks HC, Shams M, et al. Tie-2 is expressed on thyroid follicular cells, is increased in goiter, and is regulated by thyrotropin through cyclic adenosine $3^{*}, 5^{*}$-monophosphate. J Clin Endocrinol Metabol 2001; 86: 2709-16.

10. Buchanan MA, Ramsden JD, Watkinson JC, Eggo MC. Regulation of the angiopoietins in thyroid follicular cells. Endocrine 2004; 7: P247.

11. Felmeden DC, Blann AD, Lip GYH. Angiogenesis: basic pathophysiology and implications for disease. Eur Heart J 2003; 24: 586-603.

12. Gerard AC, Poncin S, Caetano B, et al. Iodine deficiency induces a thyroid stimulating hormone-independent early phase of microvascular reshaping in the thyroid. Am J Pathol 2008; 172: 748 .

13. Hussain M, Hissham AN. Total thyroidectomy: the procedure of choice for toxic goitre. Asian J Surg 2008; 31: 59-62.

14. Del Rio P, Berti M, Sommaruga L, et al. Pain after minimally invasive videoassisted and after minimally invasive open thyroidectomy-results of a prospective outcome study. Langenbecks Arch Surg 2008; 393: 271-3.

15. Lombardi CP, Rafaelli M, Princi P, et al. Safety of video-assisted thyroidectomy versus conventional surgery. Head Neck 2004; 30: 58-64.

16. Agarwal G, Aggarval V. Is total thyroidectomy the surgical procedure of choice for benign multinodular goiter? An evidencebased review. World J Surg 2008; 32: 1313-24. 
17. Kaczka K, Jankowski W, Kopczyński J, et al. Całkowita tyreoidektomia w przypadku łagodnych guzowatych chorób tarczycy w aspekcie badań funkcji krtani - czy nowy standard leczenia operacyjnego wola? Pol Przegl Chir 2010; 82: 8-20.

18. Korzeniowska M, Kołomecki K, Stępień H, et al. Czynniki proi antyangiogenne u chorych z nieczynnymi hormonalnie guzami nadnerczy. Endokrynol Pol 2005; 1: 39-44.

19. Toutounchi S, Cieśla W, Krajewska E, et al. Wyłuszczenie laparoskopowe pojedynczego guza nadnercza u pacjentki z pierwotnym hiperaldosteronizmem. Videosurgery and other miniinvasive techniques 2007; 2: 164-7.

20. Otto M, Dzwonkowski J, Ciąćka T, et al. Adrenalektomia laparoskopowa u chorych w podeszłym wieku. Videosurgery and other miniinvasive techniques 2006; 2: 54-8.

21. Lewiński A, Smyczyńska J, Hilczer M. Nadczynność i niedoczynność tarczycy - przyczyny, rozpoznawanie i leczenie. Przew Lek 2002; 5: 52-62.

22. Li Je, Zhang YP, Kirsner RS. Angiogenesis in wound repair: angiogenic growth factors and the extracellular matrix. Microsc Res Tech 2003; 60: 107-14.

23. Swidzińska E, Naumnik W, Chyczewska E. Angiogeneza i neoangiogeneza - znaczenie w raku płuca i innych nowotworach. Pneumonol Alergol Pol 2006; 74: 414-20.

24. Ramsden JD. Angiogenesis in the thyroid gland. J Endocrinol 2000; 166: 475-80.

25. Mitchel JC, Parangi S. Angiogenesis in benign and malignanat thyroid disease. Thyroid 2005; 15: 494-509.

26. Turner $\mathrm{H}$, Harris AL, Melmed S, Wass JAH. Angiogenesis in endocrine tumors. Endocr Rev 2003; 24: 600-32.

27. Wollman S, Herveg J, Zeligs J, Ericson L. Blood capillary enlargement during the development of thyroid hyperplasia in the rat. Endocrinology 1978; 103: 2306-12.

28. Figueroa-Vega N, Sanz-Cameno P, Moreno-Otero R, et al. Serum levels of angiogenic molecules in autoimmune thyroid diseases and their correlation with laboratory and clinical features. J Clin Endocrinol Metabol 2009; 94: 1145-53.

29. Lee JS, Song SH, Kim JM, et al. Angiopoietin-1 prevents hypertension and target organ damage through its interaction with endothelial Tie2 receptor. Cardiovasc Res 2008; 78: 572-80.

30. Niedźwiecki S, Stepień T, Kopeć K, et al. Angiopoietin 1 (Ang-1), angiopoietin 2 (Ang-2) and Tie-2 (a receptor tyrosine kinase) concentrations in peripheral blood of patients with thyroid cancers. Cytokine 2006; 36: 291-5.

31. Nadar SK, Blann AD, Lip GY. Plasma and platelet derived vascular endothelial growth factor and angiopoietin-1 in hypertension: effects of antihypertensive therapy. J Intern Med 2004; 256: 331-7.

32. Bourlev V, Iljasova N, Adamyan L, et al. Signs of reduced angiogenic activity after surgical removal of deeply infiltrating endometriosis. Fertil Steril 2010; 94: 1669-73.

33. Kołomecki K, Bartos M, Pomorski L, Kuzdak K. Wpływ strumektomii na stężenie VEGF w surowicy krwi u chorych z chorobą Gravesa-Basedowa. Wiad Lek 2001; 54: 9-10.

34. Caine GJ, Stonelake PS, Lip GY, Blann AD. Changes in plasma vascular endothelial growth factor, angiopoietins, and their receptors following surgery for breast cancer. Cancer Lett 2007; 248 : 131-6.
35. Caine GJ, Blann AD, Stonelake PS, et al. Plasma angiopoietin-1, angiopoietin-2 and Tie-2 in breast and prostate cancer: a comparison with VEGF and Flt-1. Eur J Clin Invest 2003; 33: 883-90. 